\title{
Structural analysis of interior layered deposits in Northern Coprates Chasma, Mars
}

\author{
F. Fueten ${ }^{\text {a, } *}$, H. Racher ${ }^{\text {a }}$, R. Stesky ${ }^{\text {b }}$, P. MacKinnon ${ }^{\text {a }}$, E. Hauber ${ }^{c}$, P.C. McGuire ${ }^{\text {c,e, },}$, T. Zegers ${ }^{\text {d }}$, K. Gwinner $^{c}$ \\ a Department of Earth Sciences, Brock University, St. Catharines, Ontario, Canada L2S 3A1 \\ ${ }^{\mathrm{b}}$ Pangaea Scientific, Brockville, Ontario, Canada \\ ' Institute of Planetary Research, German Aerospace Center (DLR), Berlin, Germany \\ d Faculty of Geosciences, Utrecht University, Utrecht, The Netherlands \\ e Institute for Geosciences, Department of Planetary Science and Remote Sensing, Freie Universitaet, Berlin, Germany
}

\section{A R T I C L E I N F O}

\section{Article history:}

Accepted 2 November 2009

Available online 5 December 2009

\section{Keywords:}

Valles Marineris

Coprates Chasma

interior layered deposits

ancestral basin

\begin{abstract}
A B S T R A C T
Interior layered deposits within an embayment on the northern wall of Coprates Chasma in the Valles Marineris, Mars, are studied using HRSC, CTX, HiRISE and CRISM data. The layered material outcrops in three separate locations. The largest layered deposit within the embayment, a free standing central mound, has an approximate stratigraphic thickness of $2 \mathrm{~km}$. Dip directions change along the central axis of this mound, which is also a zone of deformation. The surface texture of layers within this mound displays polygonal structures at HiRISE scale. By contrast, the western layered deposit abuts directly against the chasm wall and appears to have a relatively uneroded depositional surface approximately $600 \mathrm{~m}$ below the current top elevation of the central mound. A basement ridge, exposed by a landslide scar near the eastern portion of the area, is covered with layered material and shows downward displacement. We suggest that the entire embayment originated as a small ancestral basin. The displaced basement ridge is evidence of the early basin collapse. The central mound was most likely deposited on a wall rock spur. Deposition did not fill the basin evenly. The detection of hydrated sulfates attests to alteration or deposition by liquid water. Following an erosion event, which coincided with or postdated Valles Marineris formation, thin mesa-forming materials covered most of the area.
\end{abstract}

(c) 2009 Elsevier B.V. All rights reserved.

\section{Introduction}

Interior layered deposits (ILDs) occur throughout the chasms of the Valles Marineris and account for approximately $17 \%$ of the total area and $60 \%$ of all chasma deposits (Lucchitta et al., 1994). The origin and mechanism of ILD formation is uncertain. Several hypotheses are proposed, including lacustrine (Nedell et al., 1987), aeolian (Peterson, 1981), pyroclastic volcanism in subaerial (Hynek et al., 2003; Chapman, 2002; Lucchitta, 1987, 1990) or subglacial (Nedell et al., 1987; Chapman and Tanaka, 2001; Komatsu et al., 2004) environments. More recently it has been suggested that they formed as spring deposits (Rossi et al., 2008). All of these processes imply that the troughs within which the ILDs formed are older than the ILDs. Alternatively, Malin and Edgett (2000) and Catling et al. (2006) suggest ILDs are ancient deposits buried beneath the material which form the walls of troughs. The diversity of ILD characteristics implies that several mechanisms were involved in their formation.

\footnotetext{
* Corresponding author.

E-mail addresses: ffueten@brocku.ca (F. Fueten), hr04wy@brocku.ca (H. Racher), rstesky@pangaeasci.com (R. Stesky), Paula.MacKinnon@dsbn.edu.on.ca (P. MacKinnon), ernst.hauber@dlr.de (E. Hauber), mcguire@geosci.uchicago.edu (P.C. McGuire), tzegers@rssd.esa.int (T. Zegers), klaus.gwinner@dlr.de (K. Gwinner).

${ }^{1}$ Formerly at: McDonnell Center for the Space Sciences, Washington University, St. Louis, Missouri, USA.
}

The chasmata of Valles Marineris were likely formed during a two stage process (Lucchitta et al., 1994; Schultz, 1998). Ancestral basins with irregular outlines were proposed to form prior to the opening of the Valles Marineris during rift-like faulting (Lucchitta and Bertolini, 1990; Lucchitta et al., 1994). Lucchitta et al. (1994) suggest that Hebes, south Ophir, south Candor and potentially south Melas Chasma were sites of ancestral basins, while much of Coprates, north Melas and Ius may have formed during the later faulting episodes. Faulting resulting from the opening of the Valles Marineris (Schultz, 1998) connected surrounding basins and formed the current canyon configuration.

Mineralogical data from the OMEGA instrument on the Mars Express mission suggest water as a mechanism in the formation or alteration of local ILDs because of the presence of sulfates (Gendrin et al., 2005; Mangold et al., 2007a,b). More recently (Milliken et al., 2008) CRISM data revealed the presence of opaline silica to be associated with some sulfate locations on top of the plateaus surrounding the Valles Marineris troughs. Chojnacki and Hynek (2008) provide a comprehensive review of wateraltered minerals within Valles Marineris and suggest that no single formation mechanism can account for the available data. Generally, though not always, monohydrated kieserite occurs on steeper slopes while polyhydrated sulfates often form benches, knobs or hummocky terrain (Chojnacki and Hynek, 2008). The most likely reason for this difference is the relative difference in erosional resistance between mono- and polyhydrated sulfates (Chojnacki and Hynek, 2008). 
A recent model for ILD formation, based on stratigraphic and structural observations (Fueten et al., 2008) within western Candor Chasma suggests that deposition occurred synchronously with subsidence of early basins and that individual subsiding basin blocks may be identified. According to this model the deposition takes place without the formation of obvious unconformities or disconformities during the subsidence phase, but is followed by a major period of erosion, most likely associated with the linkage of basins and the establishment of drainage channels during the opening of Valles Marineris. Following that period of erosion, there is evidence for only minor subsequent deposition.

In this study, we follow the general methodology of Fueten et al. (2008) to study small layered deposits located within an embayment of Coprates Chasma to test the proposed model. What makes this area particularly interesting is that Coprates is not one of the prime candidates for an ancestral basin (Lucchitta et al., 1994). We suggest that while there are significant differences, the overall observations do indeed support the model.

\section{Geological setting}

This study area is located within an embayment on the northern wall of Coprates Chasma (Fig. 1). An anaglyph of the area is provided in Fig. 2. The southern boundary of the embayment is formed by a linear embankment trending approximately $110^{\circ}$. Along this boundary, the base of the embayment is $500 \mathrm{~m}, 1 \mathrm{~km}$ above the floor of Coprates Chasma. The largest volume of layered material within the embayment occurs as a central deposit that is approximately $12 \mathrm{~km}$ long and $8 \mathrm{~km}$ wide. (Fig. 1C,D) Also present are layered deposits to the west of the main mound (Fig. 1, WD) and some layered material to the SE of the main mound (Fig. 1, ED). In contrast to the isolated central mound, the western deposit appears to be directly in contact with the wall. This deposit is approximately $8 \mathrm{~km}$ wide and $7 \mathrm{~km}$ long. The layered material to the southeast (Fig 1, ED) within the embayment is located near the site of a major landslide structure and occurs as several small mounds.

Layered deposits within Valles Marineris show a range of layering thicknesses, albedos and erosional characteristics with varying degrees of competency and compositions (Fueten et al., 2008; Rossi et al., 2008; Catling et al., 2006; Hauber et al., 2006; Komatsu et al., 2004; Malin and Edgett, 2000; Komatsu et al., 1993). Malin and Edgett, (2000) divide the deposits into three categories; light- to intermediate-toned "layered" units, light- to intermediate-toned "massive" units, and "thin mesa" units, which consist of dark- to intermediate-toned capping units. Adopting this terminology, the three locations discussed above are composed primarily of layered units. As pointed out by Malin and Edgett (2000), thin mesa material here appears to unconformably cover some layered material (Fig. 3). Thin mesa materials (Fig. 3) also cover significant portions of the chasma walls, where they appear to have been emplaced on wall rock, and are more cratered than the exposed, eroded layered deposits. Their thickness cannot be resolved using the resolution of the HRSC DEM (Digital Elevation Model), suggesting that it is on the order of meters, rather than tens of meters. Hence they are different from the massive mesa units discussed by Fueten et al. (2008). Due to the unconformable relationship with the layered units, the thin mesa material is younger than the ILD deposits. This study focuses primarily on the underlying layered units, although we discuss the thin mesa units briefly.

\section{Mineralogical data based on CRISM analysis}

We analyzed a CRISM (Murchie et al., 2007) image (HRL00003752) of the central deposit and its surroundings. The CRISM image (HRL00003752) is shown in Fig. 4, with two spectra shown in Fig. 5.

The image was first corrected for $\mathrm{CO}_{2}$ absorption in the atmosphere by applying an improved version (McGuire et al., in preparation) of the 'volcano-scan' atmospheric-correction technique (Langevin et al., 2005) for CRISM and OMEGA data. This improved volcano-scan correction allows the Lambert albedo at $2.01 \mu \mathrm{m}$ to differ from the Lambert albedo at $1.89 \mu \mathrm{m}$, and it also corrects for a slight variation (at the level of $<0.001 \mu \mathrm{m}$ ) in the wavelengths of the CRISM detector, caused by variations in detector temperature (Smith et al., 2009).

Imaging in the near-infrared allows for the detection of minerals in the upper $0.1 \mathrm{~mm}$ of a planetary surface. In general (i.e., Murchie et al., 2009), monohydrated sulfates tend to have absorptions at $2.1 \mu \mathrm{m}$ and $2.4 \mu \mathrm{m}$, whereas polyhydrated sulfates tend to have an absorption at $1.9 \mu \mathrm{m}$ and a drop-off at $2.4 \mu \mathrm{m}$. The sulfates can be effectively mapped by spectral summary parameters (Pelkey et al., 2007), in particular the BD1900, BD2100 and SINDEX parameters. The SINDEX parameter detects convexity in the spectra centered at 2.2-2.3 $\mu \mathrm{m}$ due to simultaneous absorption at 1.9-2.1 $\mu \mathrm{m}$ and $2.4 \mu \mathrm{m}$. We have chosen rather large values for the thresholds of the spectral summary parameters in Fig. 4 in order to cut through some of the apparent effect of ice aerosols on the spectra. With the chosen values for the summary-parameter thresholds, the greatest signal of monohydrated sulfates appear in two large regions on the floor of the chasma (to the SE and to the SW) and a number of discrete locations on the wall of the mound (to the SE and from the SW to the NW). With the chosen values for the summary-parameter thresholds, the greatest signal of polyhydrated sulfates appear on the southern slopes of the mound and on the chasma floor to the north of the northern slopes of the mound.

We have double-checked this use of spectral summary parameters to map the sulfates in this mound in Coprates Chasma by plotting two spectra (averaged over $3 \times 3$ pixel $^{2}$ ) in Fig. 5 , one spectrum over the polyhydrated sulfate area on the south slopes of the mound, and one spectrum over a monohydrated sulfate area on the chasma floor to the SW of the mound. Throughout the image, all the spectra have broad absorptions in them at $1.5 \mu \mathrm{m}$ and $2.0 \mu \mathrm{m}$, suggestive of ice aerosols, which were present either when this image was acquired, or when the volcano-scan transmission spectrum was acquired. By choosing high thresholds for the spectral summary parameters, we can search for those places in the image where the sulfates on the surface are visible, despite the obscuring effects of the ice aerosols. Indeed, the maps of sulfate spectral summary parameters do appear to function: ratios of the sulfate-rich spectra to bland spectra in the same detector columns (Fig. 5) do contain the corresponding spectral features for sulfates discussed in the previous paragraph.

We have also done several spot checks (not shown here) of isolated, single pixels on the steep slopes on the west side of the mound which satisfy the thresholds for detection (given in Fig. 4) of both SINDEX and BD2100. These single pixels were located at:

(1) $X=257, Y=264$; with a bland reference pixel at $X=257$, $Y=368$

(2) $X=229, Y=307$; with a bland reference pixel at $X=229$, $Y=351 ;$ and

(3) $X=203, Y=342$; with a bland reference pixel at $X=202$, $Y=255$.

Spectral ratios of the spectra at these pixels, relative to the bland reference pixels do indeed show bands at 2.1 and $2.4 \mu \mathrm{m}$, albeit with somewhat more statistical noise than the spectral ratios shown in Fig. 5. Therefore, the small, yellow areas on the western walls of the mound in Fig. 4 do have monohydrated sulfate signatures similar to the larger yellow areas to the SW of the mound.

\section{Methodology for attitude measurements}

High Resolution Stereo Camera (HRSC; Jaumann et al., 2007) panchromatic orthoimages, obtained during orbits 2028 and 2039, with a resolution of $12.5 \mathrm{~m}$ per pixel and corresponding Digital 

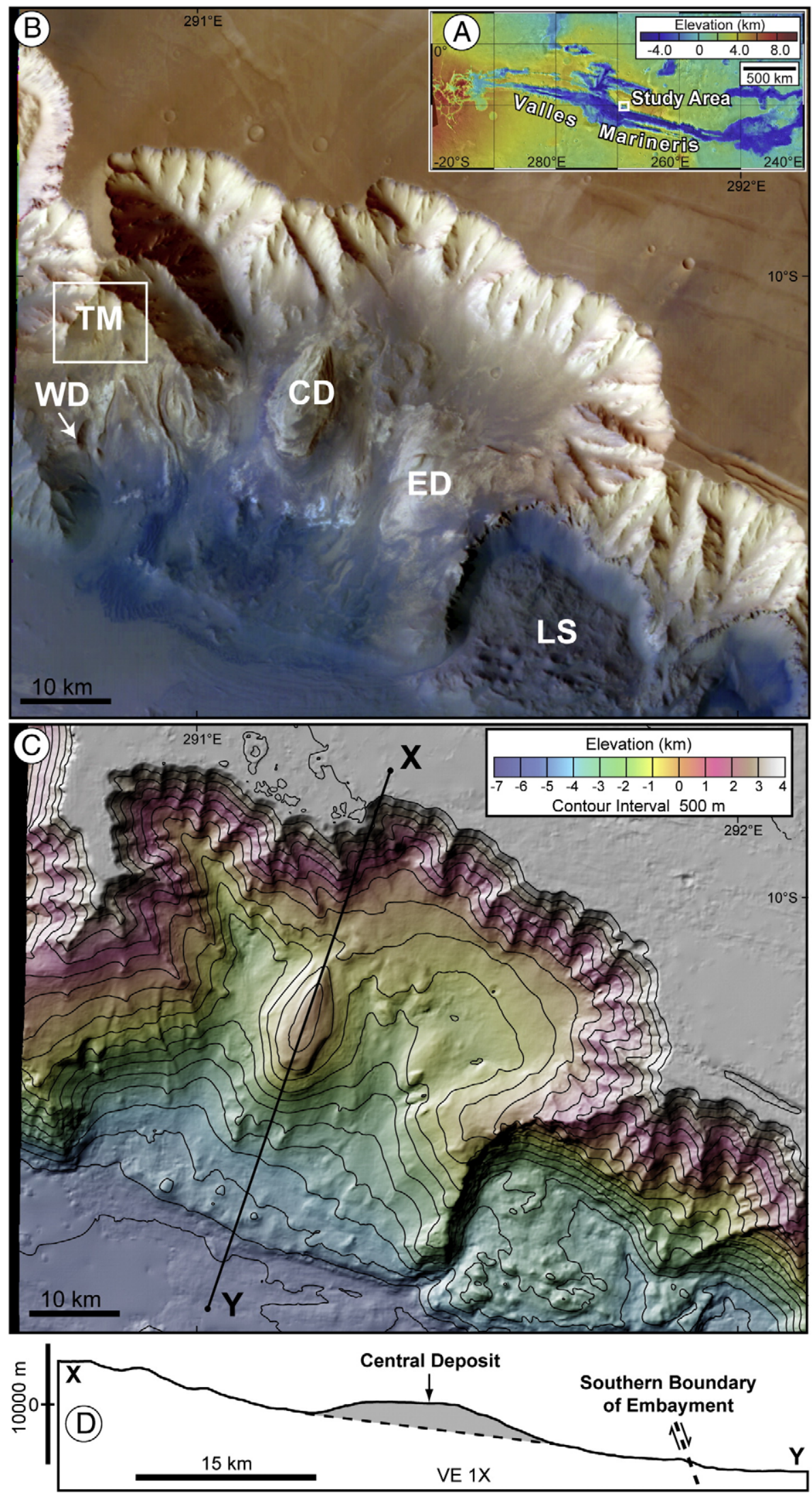

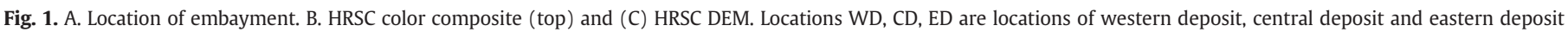

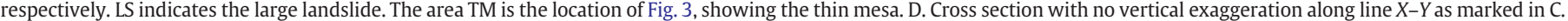

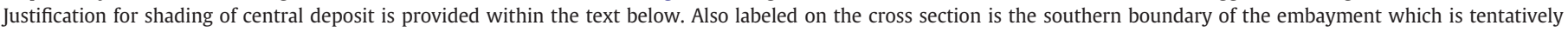
indicated as a normal fault. 


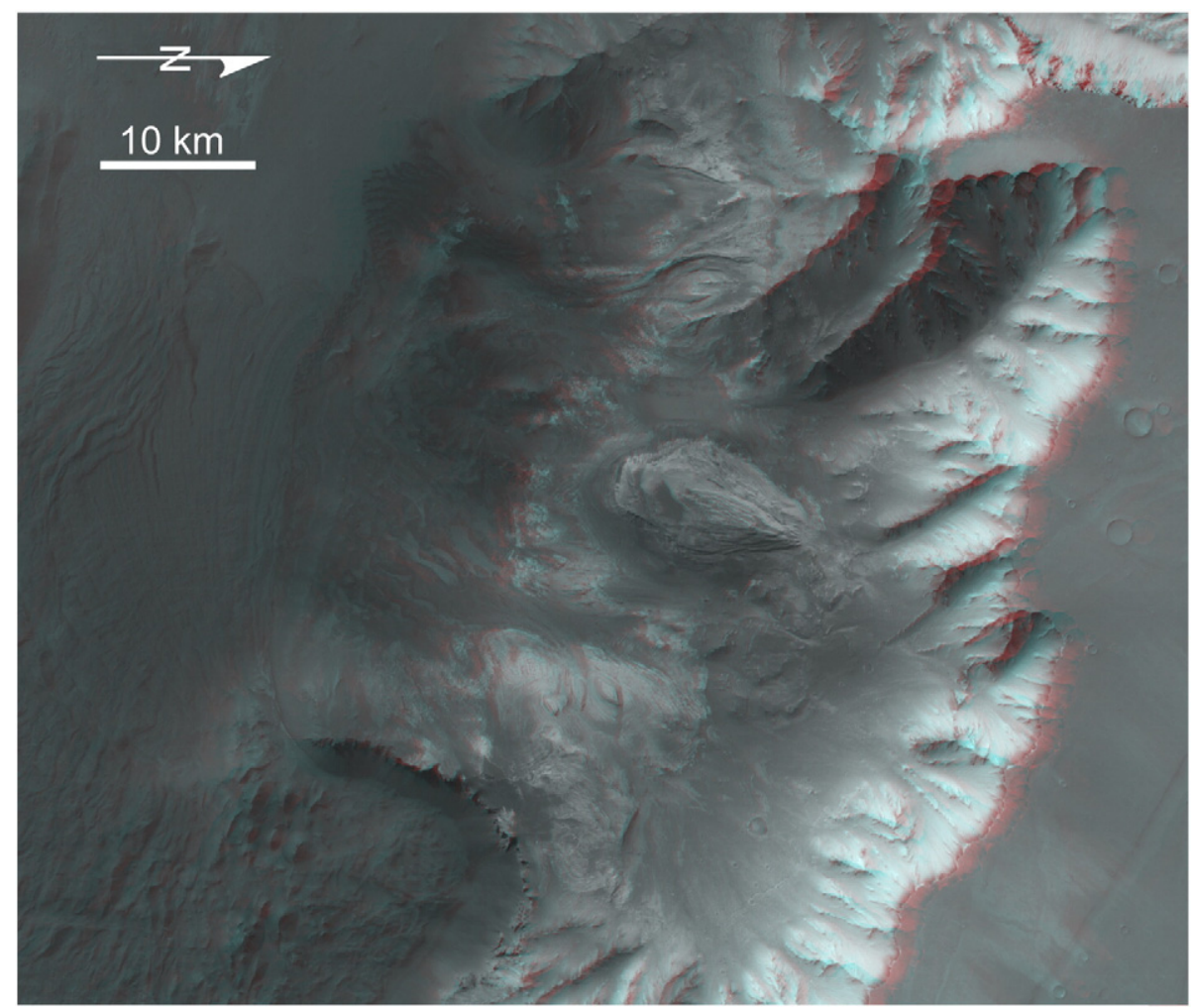

Fig. 2. Anaglyph of the study area, prepared from HRSC stereo pairs.

Elevation Model (DEM) with a grid spacing of $50 \mathrm{~m}$ form the primary data set for this study. In addition, a mosaic of three Context Camera images (CTX; Malin et al., 2007) (P02_001865_1697_XI_10S068W,
P07_003632_1681_XI_11S068W, P08_004054_1688_XI_11S069W; all with a spatial resolution of $6 \mathrm{~m}$ per pixel) was constructed and registered to the HRSC image and hence its corresponding DEM.

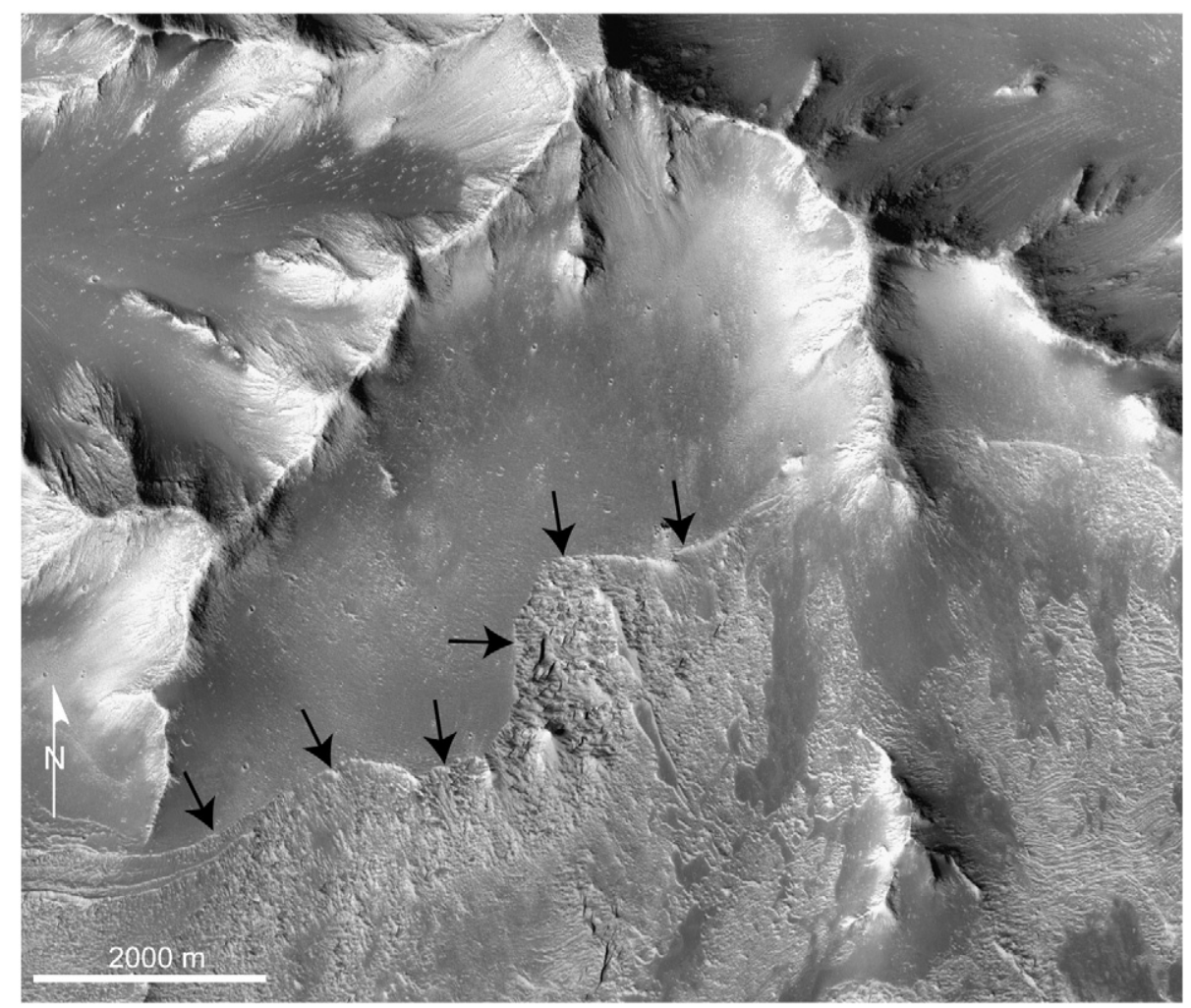

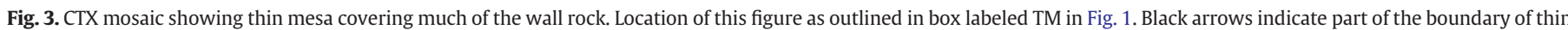
mesa material. 

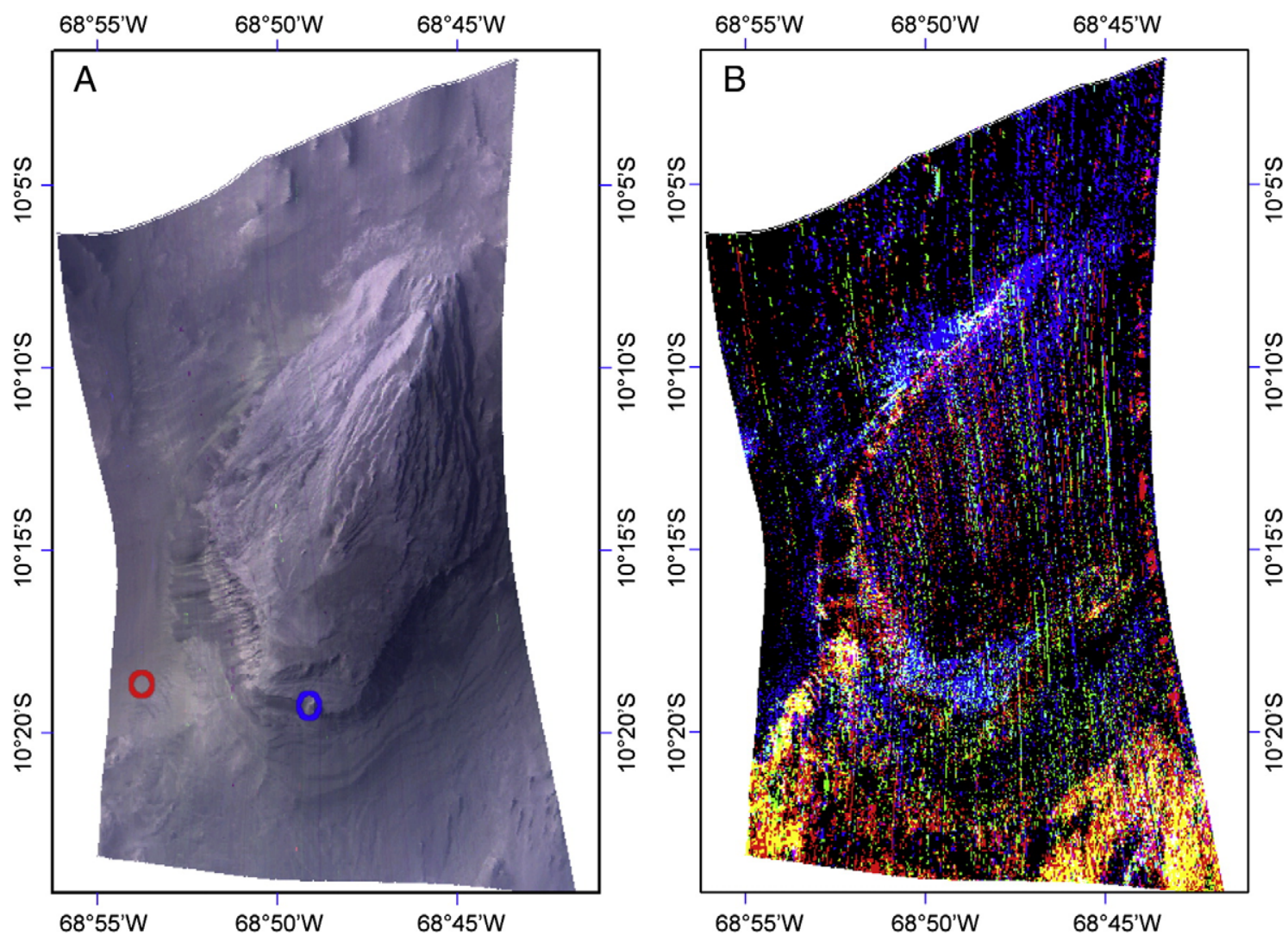

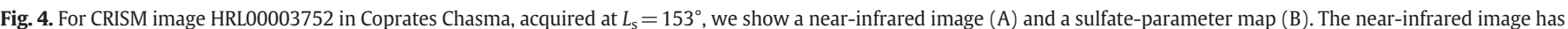

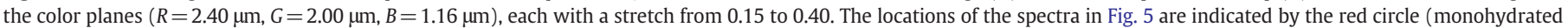

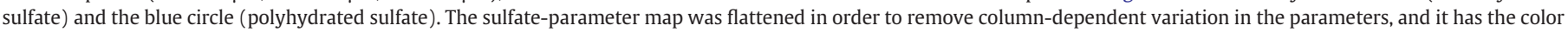

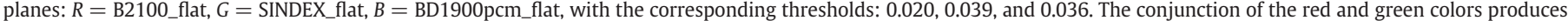

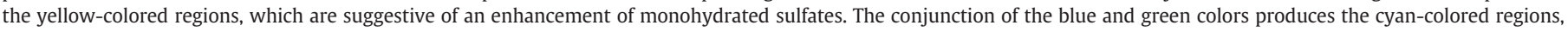
which are suggestive of an enhancement of polyhydrated sulfates.

Layering attitudes were measured on both the HRSC image as well as the CTX composite using the software package Orion following the methodology discussed in detail by Fueten et al. (2005). Where the same layer could clearly be identified in both images, measurements on different images were in good agreement (Table 1). Due to the higher resolution of the CTX image more layers could be measured within the CTX composite and therefore, with one exception, data presented below is that from CTX images. Layering of the eastern deposit straddles the seam between two CTX images which could not be perfectly matched. Hence, HRSC-based measurements are used for this location.

A HiRISE (High Resolution Imaging Science Experiment; McEwen et al., 2007) image (PSP_001456_1695) was also used for observations but not registered to the DEM because of the large difference in horizontal scale.

\section{Observations}

\subsection{Central deposit}

The long axis of the central deposit is distinctly elevated above the surrounding floor over a distance of $14 \mathrm{~km}$ (Fig. 6). South of the steep embankment that forms the obvious edge of the deposit, layers can be seen extending several kilometers further to the south (Fig. 7). If these layers are also part of the deposit, then its minimum north-south extent is approximately $17 \mathrm{~km}$. Following similar arguments, its eastwest extent is up to $10 \mathrm{~km}$. The top of the deposit is nearly horizontal along the $\mathrm{AB}$ section with a slope of less than $1.5^{\circ}$ to the south. No contact between the layered deposit and basement (i.e., chasma wallrock) can be identified; hence the base of the deposit could only be estimated. Linking inflection points in the topographic profile along $X-Y$ (Fig. 1C), the underlying basement wallrock was estimated to dip uniformly to the south at an angle of $7^{\circ}$ (Fig. 1D). Using this assumed basement contact, we estimate a stratigraphic thickness of $2 \mathrm{~km}$. The maximum absolute elevation of the central deposit, approximately $200 \mathrm{~m}$, is also the maximum elevation at which layered deposits can be identified within the embayment. This elevation is approximately $3.4 \mathrm{~km}$ below the elevation of the plateau $(3.6 \mathrm{~km})$. By comparison, other ILD deposits within Valles Marineris occur at elevations of less than $1 \mathrm{~km}$ below the local plateau (Quantin et al., 2006; Hauber et al., 2006; Lucchitta et al., 1994).

The layering attitudes within the central deposits appear to vary systematically with location as well as stratigraphic position. Layers east of the long axis of the deposit dip to the east, while those on the west side dip westerly. Layers lower in the stratigraphy tend to dip more steeply than those at higher elevations and layering on the top of the mound is nearly horizontal with a dip between $2^{\circ}$ and $6^{\circ}$. The layering in the lower west and east stratigraphy dips between $10^{\circ}$ and $20^{\circ}$. Layering to the far west dips the steepest with an angle in the range of $20^{\circ}$ to $35^{\circ}$. As stated above, layering exposed at the base of the mound appears to be largely covered by thin mesa. This layering cannot be measured with any accuracy. The difficulty of measurement could be due to the mesa covering, or because the layering has been deposited on an uneven substrate making its orientation highly variable over short distances.

Layering as observed in HiRISE image PSP_001456_1695 appears as banded light and dark lithologies (Fig. 8A). Some of the dark layers are surficial material that has accumulated on the ledges of more 

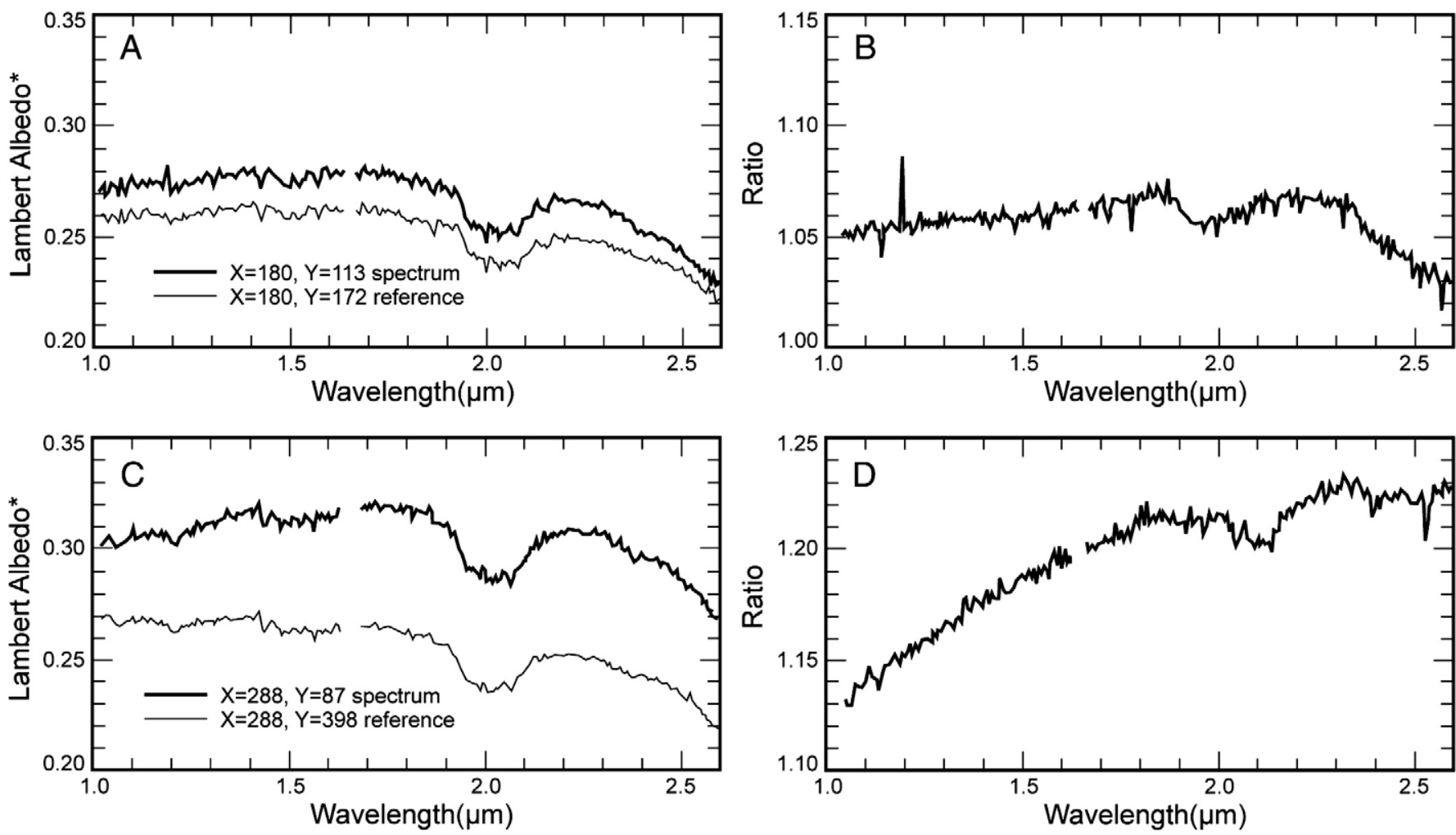

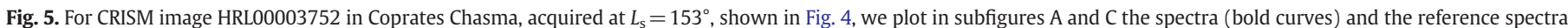

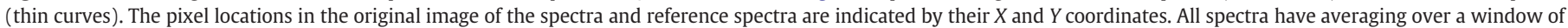

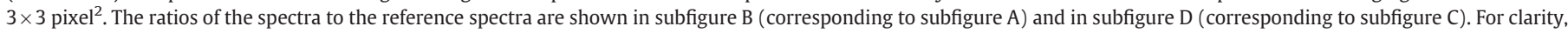

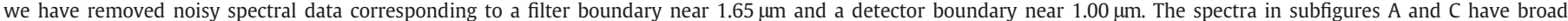

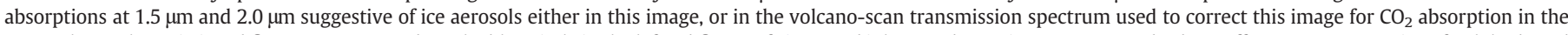

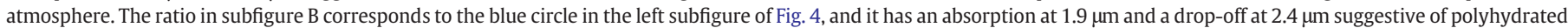

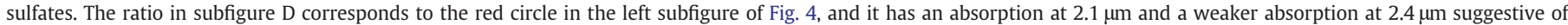
monohydrated sulfates.

resistant layers, while other layers can be distinguished by different densities of fractures (Fig. 8B). Using the horizontal width of layers displayed within the HiRISE image and inclination of the local slope from the HRSC DEM, we can estimate the layer thicknesses. Thickness of dark layers ranges from approximately $2.5 \mathrm{~m}$ to $7 \mathrm{~m}$ while light layers are generally thicker, ranging from approximately $6.5 \mathrm{~m}$ to $11 \mathrm{~m}$. Primarily the light layers are disrupted into polygons, the smallest of which are near the $25 \mathrm{~cm} /$ pixel resolution of the HiRISE image. Most polygons range in size from approximately 3 to $7 \mathrm{~m}$ in diameter. The boundaries of the polygons commonly show parallel alignment suggesting tectonic influence (Fig. 8A,B). Similar, though less deformed, polygons have been described within light toned layering in HiRISE images by Weitz et al. (2008) and Pondrelli et al. (2008). Pondrelli et al. (2008) suggest the light toned beds were disrupted into polygons through tectonic stress or thermal contraction and later deformed. Weitz et al. (2008) propose thermal contraction or desiccation of hydrated minerals as a possible formation mechanism. Schieber (2007) argues that a structure size of approximately 1-6 $\mathrm{m}$ is too large to have resulted from the desiccation cracking of mudstone.

A zone of deformation has been traced as trending approximately $025^{\circ}$, along the long axis of the mound (Fig. 7). Layering appears to be more deformed to the west of the zone of deformation. The disturbed layering appears to be smoothly folded (Fig. 8B) and no significant or

Table 1

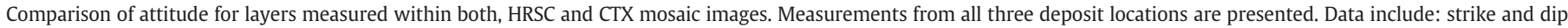

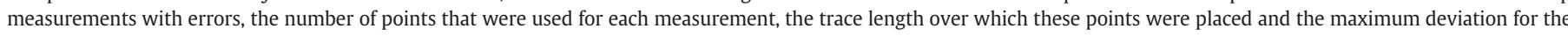
furthest point from the calculated plane. All planes have correlation coefficients greater than 0.99760.

\begin{tabular}{|c|c|c|c|c|c|c|c|c|c|c|}
\hline & \multicolumn{2}{|l|}{ HRSC } & \multicolumn{2}{|l|}{ CTX } & \multicolumn{3}{|l|}{ HRSC } & \multicolumn{3}{|l|}{ CTX } \\
\hline & Strike & Dip & Strike & Dip & \# of points & $\begin{array}{l}\text { Trace length } \\
\text { (m) }\end{array}$ & $\begin{array}{l}\text { Max. deviation } \\
(\mathrm{m})\end{array}$ & \# of points & $\begin{array}{l}\text { Trace length } \\
(\mathrm{m})\end{array}$ & $\begin{array}{l}\text { Max. deviation } \\
\text { (m) }\end{array}$ \\
\hline \multirow[t]{5}{*}{ Central mound } & $218.7 \pm 15.1$ & $4.4 \pm 1.4$ & $220.9 \pm 17.8$ & $4.5 \pm 1.6$ & 8 & 1398 & 0.83 & 16 & 2197 & 3.00 \\
\hline & $65.8 \pm 6.6$ & $14.5 \pm 1.8$ & $66.2 \pm 7.0$ & $8.4 \pm 1.4$ & 10 & 1704 & 3.20 & 8 & 1311 & 1.12 \\
\hline & $76.6 \pm 4.8$ & $10.1 \pm 1.2$ & $80.2 \pm 7.3$ & $8.8 \pm 1.7$ & 9 & 2423 & 2.19 & 11 & 1443 & 1.52 \\
\hline & $211.6 \pm 6.5$ & $13.6 \pm 1.8$ & $212.8 \pm 7.2$ & $12.2 \pm 1.8$ & 9 & 1591 & 1.41 & 13 & 1368 & 0.83 \\
\hline & $198.2 \pm 1.9$ & $17.3 \pm 0.7$ & $199.0 \pm 3.1$ & $16.5 \pm 1.3$ & 8 & 773 & 0.23 & 7 & 865 & 0.27 \\
\hline \multirow[t]{2}{*}{ West deposit } & $343.6 \pm 33.1$ & $9.2 \pm 1.7$ & $319.6 \pm 11.8$ & $9.8 \pm 1.7$ & 7 & 2062 & 2.87 & 11 & 1765 & 2.43 \\
\hline & $60.2 \pm 4.5$ & $18.7 \pm 0.9$ & $62.3 \pm 7.5$ & $18.4 \pm 1.9$ & 6 & 1460 & 0.35 & 11 & 1204 & 2.77 \\
\hline \multirow[t]{3}{*}{ East lobes } & $127.2 \pm 3.2$ & $11.5 \pm 0.6$ & $115.9 \pm 7.2$ & $12.5 \pm 2.1$ & 7 & 1320 & 0.32 & 7 & 1388 & 1.59 \\
\hline & $179.3 \pm 9.4$ & $14.8 \pm 1.1$ & $181.7 \pm 14.6$ & $14.6 \pm 1.6$ & 8 & 889 & 1.2 & 8 & 1238 & 3.14 \\
\hline & $186.6 \pm 8.5$ & $10.1 \pm 1.7$ & $174.0 \pm 5.9$ & $7.0 \pm 1.2$ & 6 & 957 & 0.64 & 7 & 821 & 0.40 \\
\hline
\end{tabular}




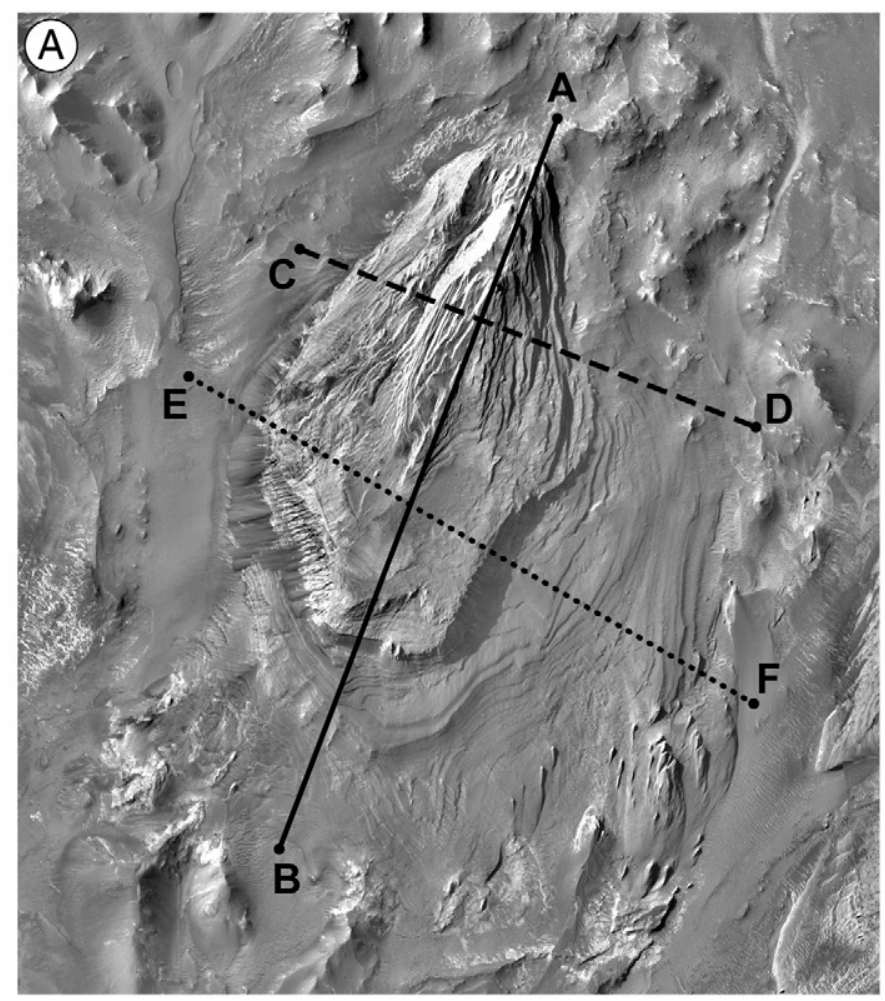

(B)

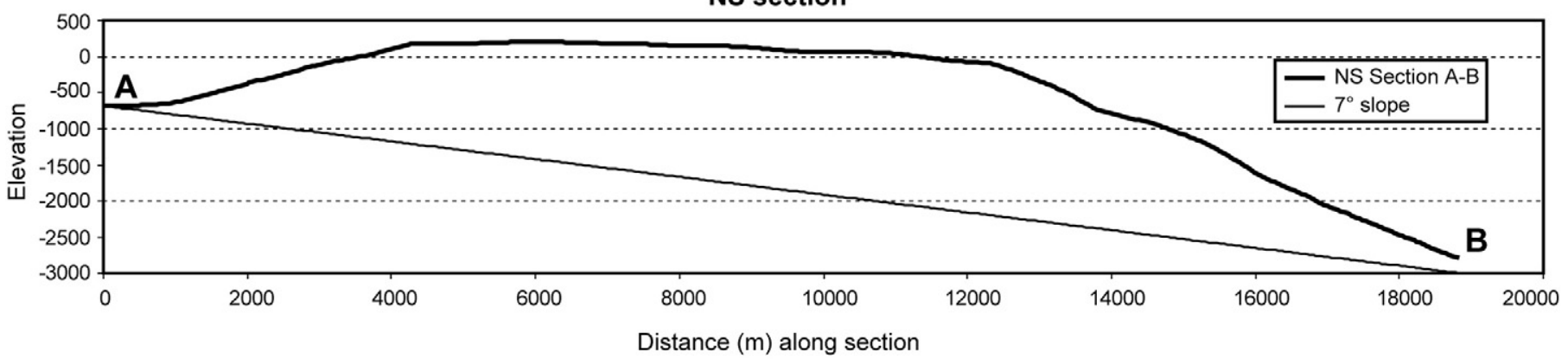

(C)

EW sections

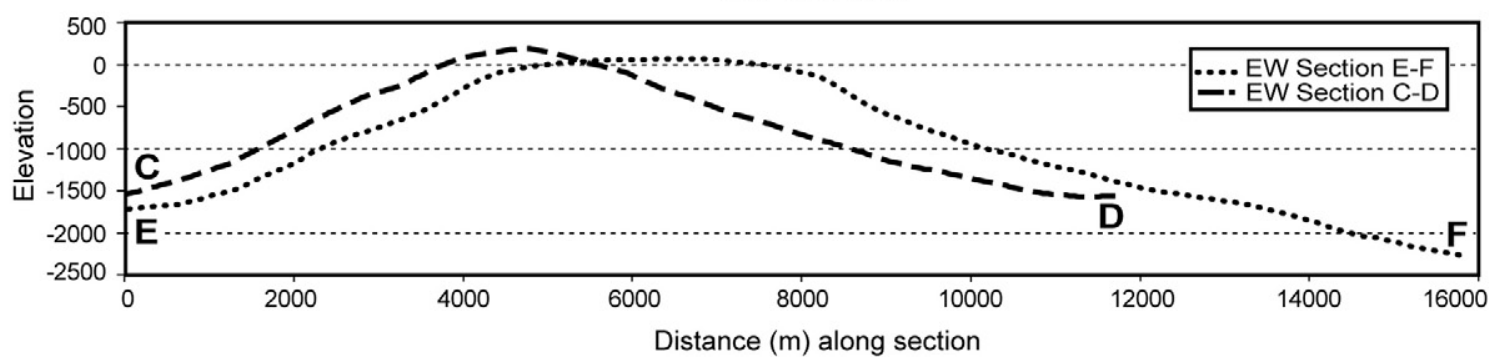

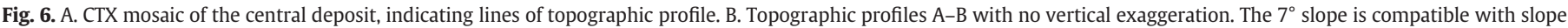

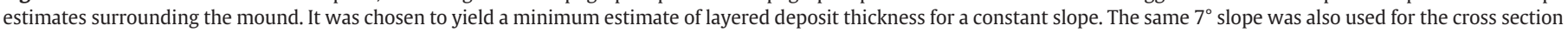
in Fig. 1. C. Topographic profiles C-D and E-F with no vertical exaggeration.

consistent offsets between layering can be detected. The zones of disruption may be similar to bounding bands (Okubo et al., 2009) though the sectioning effect of gently dipping topography and layers likely make the disruption appear to be more severe than it is.

A series of linear scarps are displayed on either side of the central mound (Fig. 7). The scarps appear to steeply cut the shallow layering, though the difference in the scale of the scarps and the DTM do not allow for the measurement of the dip of any particular scarp. East of the central axis of the mound these scarps trend between $020^{\circ}$ to $040^{\circ}$, while west of the mound the scarp trend is in the $350^{\circ}$ to $015^{\circ}$ range. They are symmetrical about the zone of disrupted layering that runs down the central axis of the mound. Their linearity and consistent attitude on either side of the mound suggest that these scarps are related to the faulting along the central axis.

The NE portion of the mound has two planar surfaces cutting the stratigraphy with similar orientations of $220^{\circ} / 33^{\circ}$ for the one 


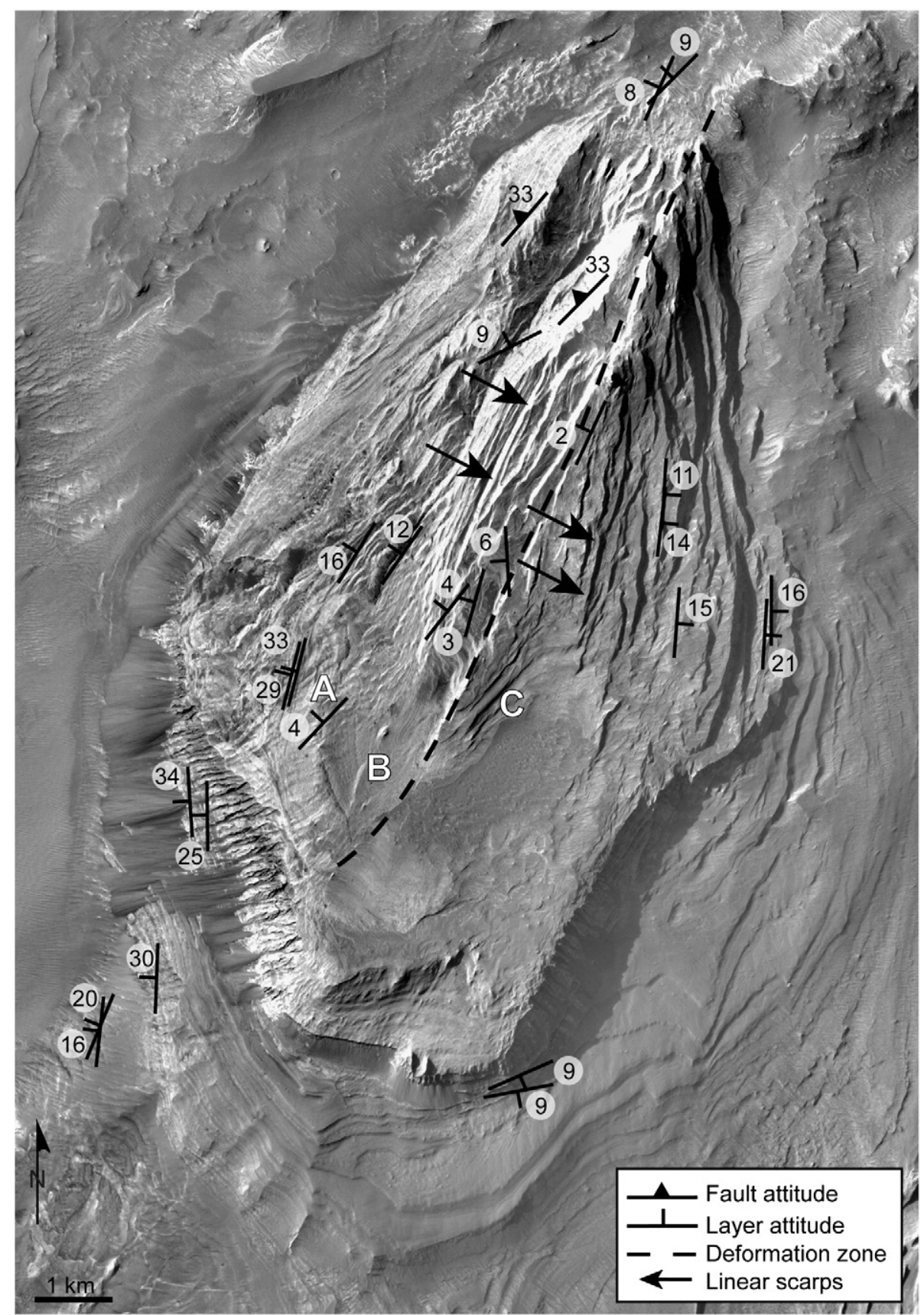

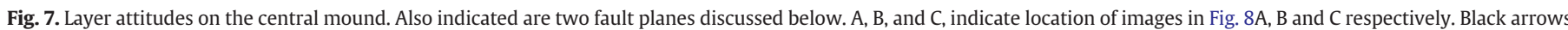
indicate examples of linear scarps discussed below.

spanning the lower stratigraphy level and $223^{\circ} / 33^{\circ}$ for the one covering the higher elevations (Fig. 7). The strike-parallel extent of the planar portion of these surfaces is approximately $2.5 \mathrm{~km}$ for the lower one and $2 \mathrm{~km}$ for the upper. Similar features within western Candor Chasma have been interpreted as fault planes (Fueten et al., 2007, 2008).

Also visible within the HiRISE images are fracture sets (Fig. 8C) which appear to be more prominent in the eastern portion of the mound. Here, two perpendicular fracture sets occur with SW-NE and NW-SE orientations. The SW-NE fracture set is dominant with longer fractures. The fracture sets do not offset layering and appear to be similar to those described by Okubo and McEwen (2007) within a finely layered sequence of ILD material with a kieserite signature. Okubo and McEwen (2007) suggest that sub-surface fluid flow was responsible for the alteration of rocks in the fracture zone and its surroundings.

\subsection{Western deposit}

The western deposit is not free standing; the northern edge of its main body directly abuts against chasma wall rock. A smaller, free standing mound is located to the south of the main body (Fig. 9). As seen in the central mound, layering covered by thin mesa material can be identified south of the elevated layered material. The top surface of the mound is partially covered by the thin mesa unit. This surface is also very planar and parallel to layering visible beneath it, dipping approximately $15^{\circ}$ to the SW. The absolute elevation of this surface ranges from approximately $-1200 \mathrm{~m}$ at its southern extent to approximately $-800 \mathrm{~m}$ at its northern extent. A distinct change in albedo occurs approximately $200 \mathrm{~m}$ below the top surface on the southernmost face of the exposure. The surface defining this change dips $10^{\circ}$ to the NE. Layering cannot be clearly identified or measured 

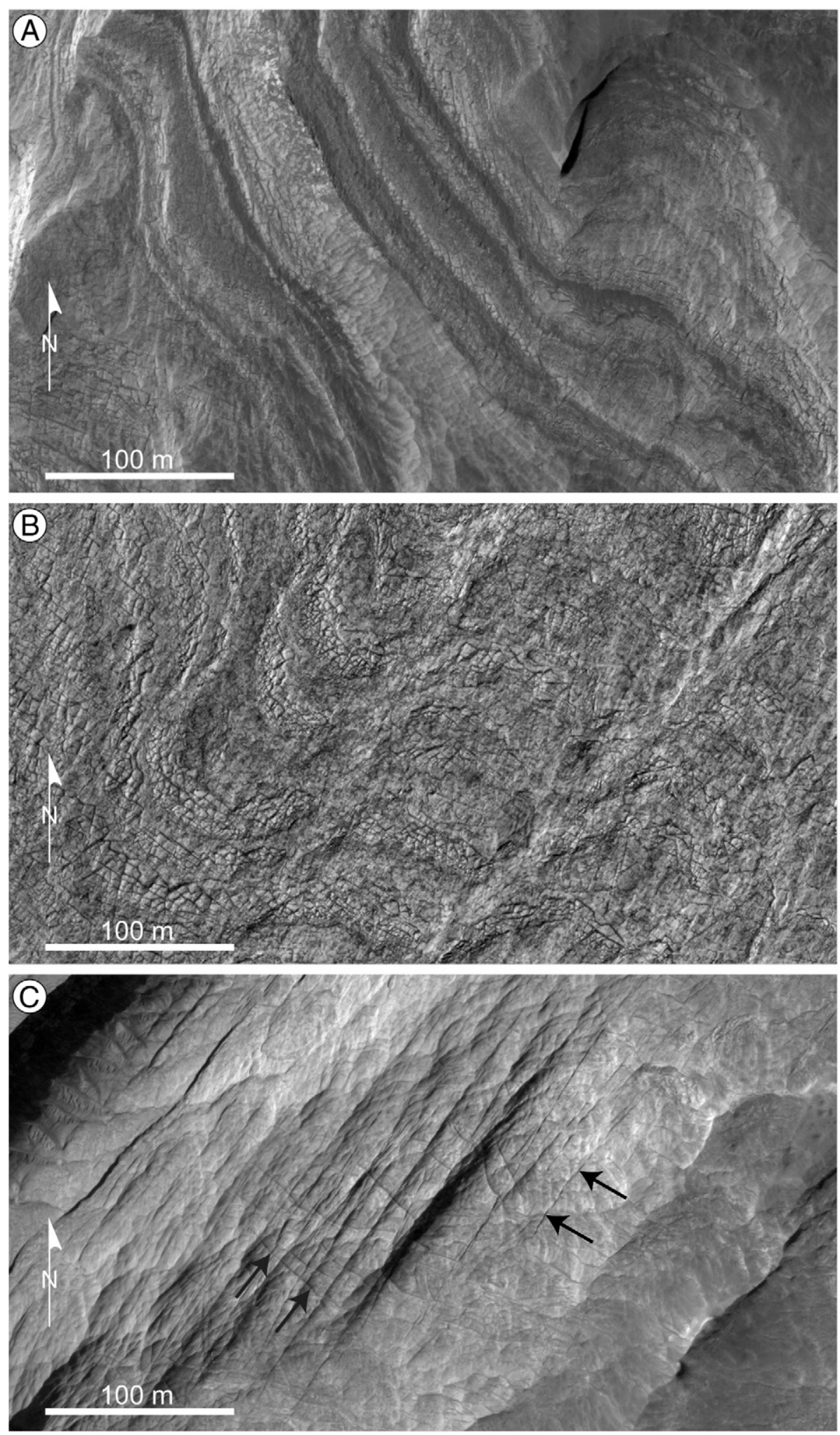

Fig. 8. HiRISE image PSP_001456_1695. A. Light and dark layering with polygonal structures. B. Disrupted layering with polygonal structures. C. Fracture sets on the east side of the mound. Black arrows point to examples of fractures.

below this surface. The darker material above this surface appears to be more massive and differs from the generally light toned layered deposits in this embayment. It may be similar to massive units described by Malin and Edgett (2000) or Fueten et al. (2008), making it the only such unit within this embayment.

\subsection{Eastern deposit}

Layered deposits within the eastern ILD of the embayment consist of several small mounds (Fig. 10). They are surrounded by a larger region of visible layering from which no attitude measurements could be 

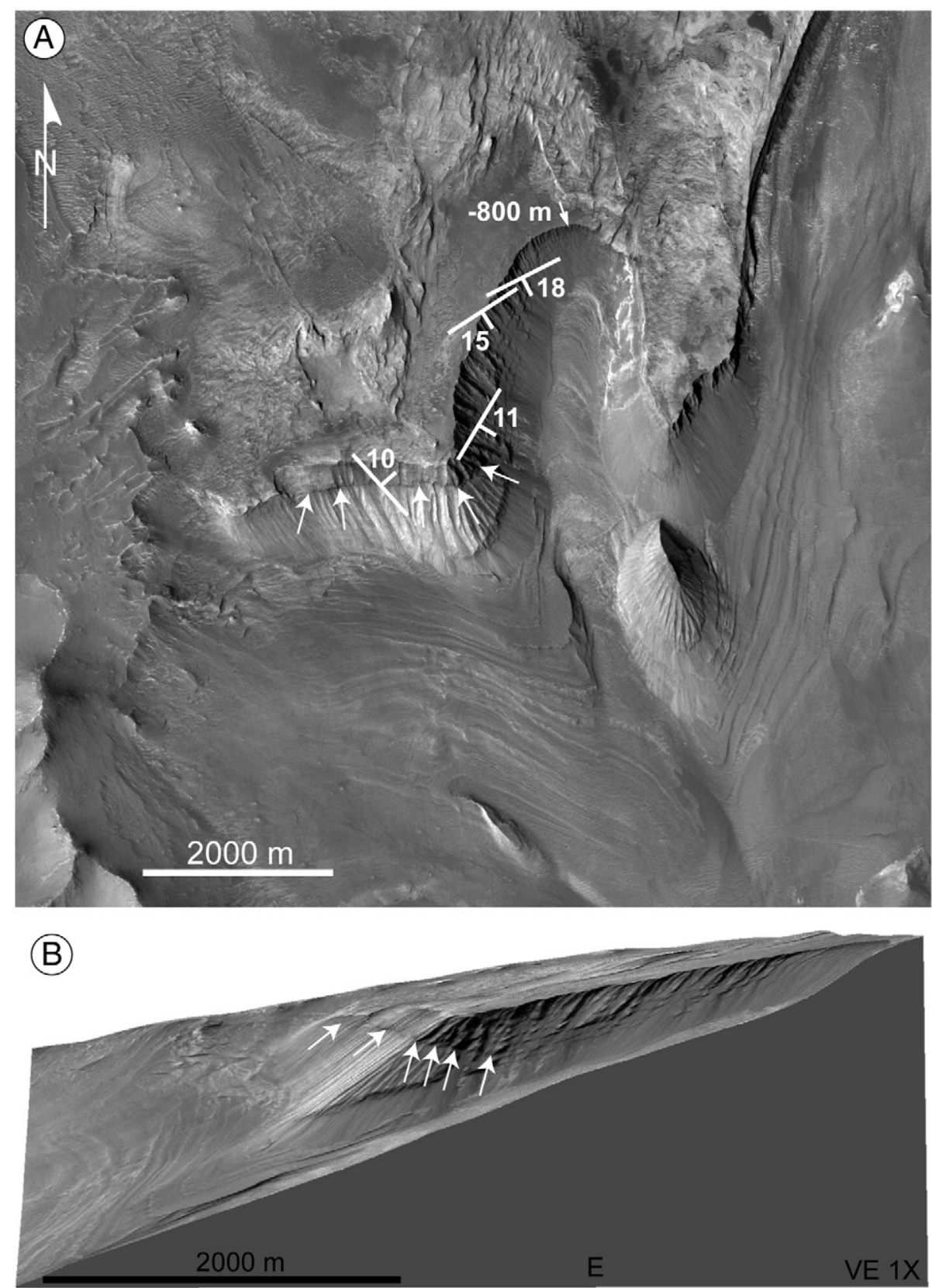

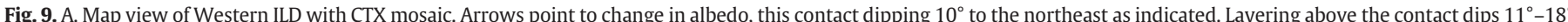

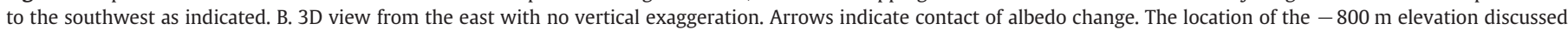
within the text is indicated.

obtained. Thin mesa material appears to cover layered units along much of the edge of the larger region. The regional slope dips approximately $16^{\circ}$ to the southwest. Only one measurement of the larger, basal layering could be obtained and it is nearly parallel to the regional slope. As stated above, irregularity within the substrate over which the layered material was deposited may account for the lack of measurements. On one of the mounds, two layer measurements indicate dips of $20^{\circ}$ and $24^{\circ}$ towards the south. Near the edge of the slump structure, fine layered material appears to dip shallowly to the west or southwest. A small remnant of thin mesa material dips $9^{\circ}$ to the west.

In the southeastern portion of the area a large landslide has exposed a section of chasma wallrock which displays layering at an elevation of approximately $-1 \mathrm{~km}, 4.5 \mathrm{~km}$ below the local plateau elevation (Fig. 10). This layering, although well exposed, cannot be measured because it is non-planar. The ridge in the central portion of wall rock in Fig. 10B is $200 \mathrm{~m}$ to $400 \mathrm{~m}$ lower in elevation in the center than it is on either end, forming a depression. While no plane can be fitted through the entire trace of this exposure, the southwestern and northeastern portions of this ridge can be approximated to be planar. The southwestern portion dips $7^{\circ}$ to the NE, while the northeastern portion dips $19^{\circ}$ to the SW, forming the geometry of a gentle southeasterly plunging fold.

The central wall rock portion is covered by layered material. The lowest levels of this material conform to the wall rock geometry, paralleling the depression, while the upper layers are less curved giving the impression that this layering has filled in the depression. The layered unit is capped by thin mesa material which dips $8^{\circ}-9^{\circ}$ to the west. 

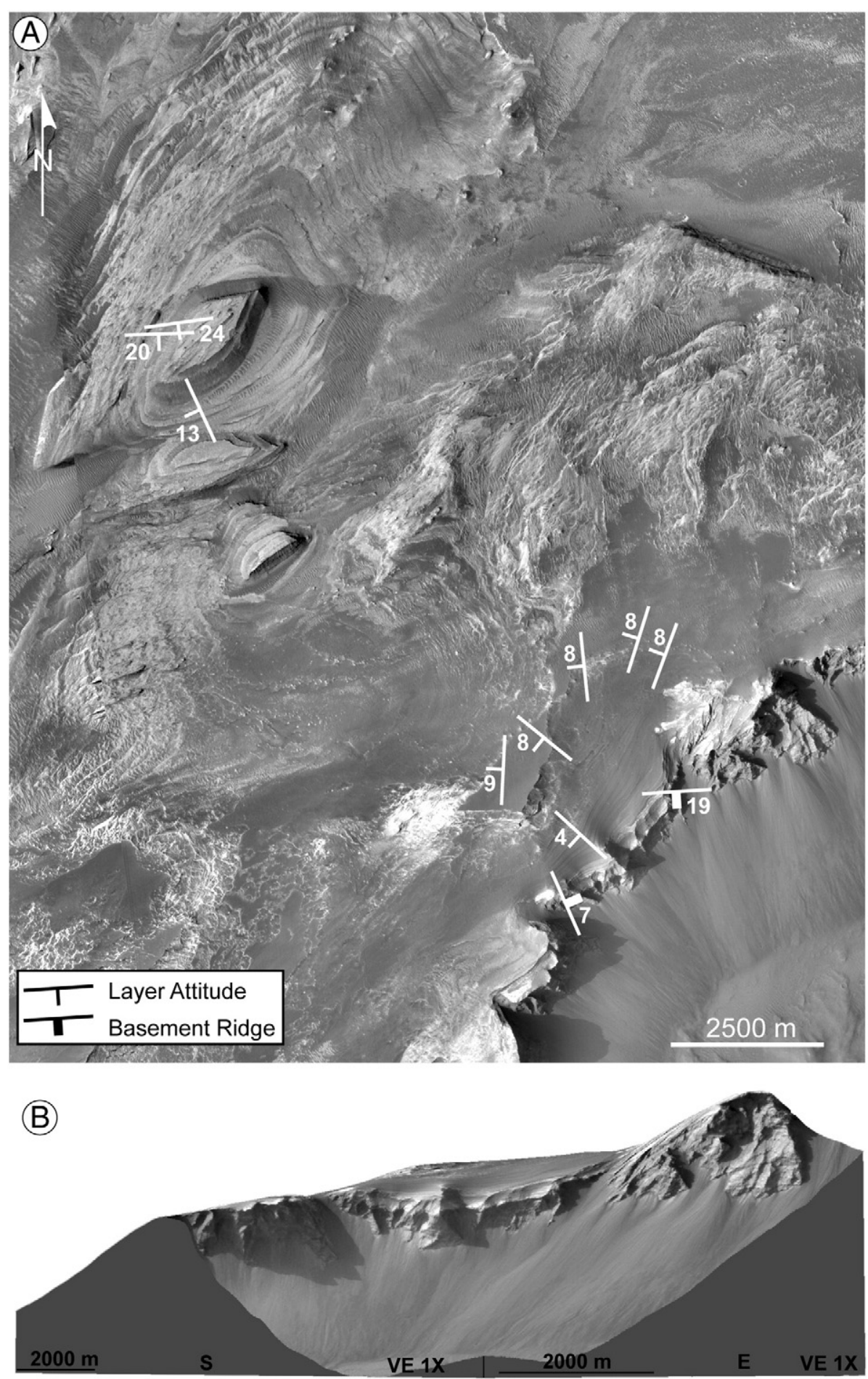

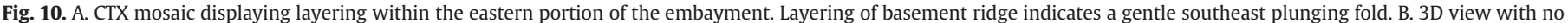
vertical exaggeration, illustrating the curvature of the central basement ridge.

\section{Discussion}

\subsection{Mineralogical data}

In other areas of Valles Marineris, it appears (i.e., Mangold et al., 2008) that the stronger monohydrate sulfates are more common in steeper parts of layered deposits whereas weaker polyhydrated sulfates appear to be less common in steeper portions of layered deposits. Herein, we do not identify the type of monohydrated sulfates. However, for reference, typical examples of monohydrated sulfates include kieserite and szomolnokite. The results of the analysis of this image of the mound in Coprates Chasma appear to be largely consistent with monohydrated sulfates being more common in wall rock than polyhydrated sulfates. The signal for monohydrated sulfates appears to be more common than the signal for polyhydrated sulfates in the steeper slopes on the west side of the mound. Polyhydrated sulfates also appear in the mound on the southern flank, but the slopes there appear to be shallower, in general. Hence, the data in this area appear to follow the general trends observed by Chojnacki and Hynek (2008). 


\subsection{Early basin}

It has been suggested that layered deposits are deposited in early ancestral basins, which are later linked during the formation of Valles Marineris (Lucchitta et al., 1994; Schultz, 1998). The wall embayment in which layered deposits examined here are located is one of the largest along the northern wall of Coprates Chasma and has a complex geometry. While other slump-related embayments open into the chasm (i.e., they get wider towards the chasm), the curvature of this embayment actually narrows in the direction of the chasma (Fig. 1A, $B$ ). The linear nature of the southern boundary of the embayment and the associated drop in elevation suggests that it is formed by one of the major faults associated with Valles Marineris tectonism (Schultz and Lin, 2001; Mège and Masson, 1996) The size of the embayment is comparable to the size of several small basins within the Tharsis Plateau (e.g., eastern Tithonium). The layered deposits occur at elevations within the approximate range of $-1 \mathrm{~km}$ to $-3 \mathrm{~km}$ which is the same range of depths of these isolated basins on the Tharsis Plateau, but well above the local floor of Coprates $(-5.5 \mathrm{~km})$. Hence we suggest that this embayment represents the remnants of a small ancestral basin. The exact geometry of this basin is not known since the main Valles Marineris opening removed its southern portion, leaving the northern remnant in its present position.

If the embayment is indeed part of an ancestral basin, an interesting suggestion can be offered for the wall rock deformation described above that has been exposed by the large landslide in the southeastern corner of the area. The wall rock depression is overlain by a sequence of layered material which decreases in curvature up the stratigraphic section and is capped by a planar thin mesa unit. This observation suggests that the depression predates the deposition of layered material. We will argue later that ILD deposition predates the linking of basins and the opening of the main linear troughs of Valles Marineris. If deposition of layered material is linked to the basin formation, the observed wall rock deformation may thus be the result of early basin collapse. It has been speculated that the size of collapsing floor segments would likely have been several square kilometers in area (Fueten et al., 2008). The displaced wall rock segment is approximately $2 \mathrm{~km}$ in width and would thus dimensionally fit well.

\subsection{Deposition of layer deposits}

Layering of the central deposit is more inclined at lower stratigraphic levels, while dips near the top of the mound are nearly horizontal, as is the actual erosional surface. None of the basal layering attitudes at any of the three locations could be measured with confidence, suggesting that these layers are not planar. These observations are compatible with layered material that is initially deposited on an inclined, irregular surface, such as the exposed wall rock slopes on the edges of the chasma. In this scenario, basal layers draping over the irregular surfaces would not be planar and planar layering could only be expected after some stratigraphic thickness had been build up. The steeper dips of $20^{\circ}-35^{\circ}$ are similar to the slopes that can be measured on the sides of wall rock spurs, which may be similar to the basement beneath the layered deposits. The geometry of the eastern deposit suggests that it was deposited directly against wall rock and thus would have to conform to it at its base. While its basal layers could not be measured, wall slope measurements surrounding the deposit range from $10^{\circ}$ to $25^{\circ}$.

A gradual decrease in dip at higher stratigraphic levels would be expected in a depositional setting in which externally delivered material is deposited on an inclined surface. This contrasts directly with the expected geometry in which a mound is built up from an internal material source. In such an environment, e.g. a volcano or spring deposit layering dip might be expected to increase higher in the section. However, as pointed out by Rossi et al. (2008) the geometry of spring deposits may be very complex.
A zone of deformation transects the central mound, trending approximately $20^{\circ}$. Layer dip directions differ on either side of this zone, as does the average trend of the larger scarps. However, no significant offsets can be observed across the layering. Hamelin et al. (2008) suggested that an active fault, trending approximately $025^{\circ}$, was located near the center of the central mound and that tectonism continued beyond deposition after the mound had lithified. The lack of significant offsets suggests that fault motion was minor. While it may be possible that a fault lies beneath the central axis of the central mound, we found no evidence for the extension of such a fault north or south beyond the mound.

An alternative suggestion is that the central mound material was deposited on top of a wall spur and that dip directions on either side of the mound simply mimic those of the underlying wall rock dip. Compaction and quakes during tectonism could then account for some of the disruption along the central axis as material would tend to move down the local underlying wall rock slope. In this scenario, the linear scarps are most likely tensile features, produced by the motion of material, either during tectonism or simply compaction. This argument is also not without problems because in typical spur geometry, strike directions on either side of the spur converge down slope. Gravity driven tensile features would be expected to mimic this geometry. However, the orientations of the linear scarps show the opposite sense of convergence. The elevation north of the mound is approximately $1 \mathrm{~km}$ higher than the elevation south of the mound, leaving no doubt as to the wall rock slope. Hence, an underlying wall rock spur would require an unusual geometry to fit the observations. Nevertheless, in the complete absence of any data on the underlying basement geometry, we favour this interpretation for its overall simplicity.

One important aspect to consider is the original extent of these deposits. The discussions above have focused on exposed layered deposits. However the northwestern portion of the embayment is covered by thin mesa material and devoid of the rugged wall rock spurs. This region has an absolute elevation of approximately $-300 \mathrm{~m}$, below the maximum height at which layered deposits occur within the embayment and slopes between $7^{\circ}$ and $10^{\circ}$. It has been already been suggested that thin mesa units have thicknesses on the order of meters and are thus unlikely to be able to cover and smooth out wall rock topography with irregularities (e.g. spurs) on the order of tens to hundreds of meters. Hence it is possible that this region is also covered by layered deposits which are themselves covered by thin mesa material.

All three deposits show clear signs of erosion. The small mounds of the eastern deposit may well have been linked, but their current appearance does not provide any evidence to suggest their original extent. The top surface of the western deposit however is very planar and parallel to layering underneath it. It may thus represent, or closely resemble, the top of the original depositional surface. Its maximum elevation of approximately $-800 \mathrm{~m}$ is approximately $600 \mathrm{~m}$ below the maximum elevation of the central mound. This suggests that it is unlikely that the entire ancestral basin represented by this embayment was filled to the same level. The current geometry of the embayment indicates that the western deposit was within the same basin as the central mound. Many of the larger ILDs studied (Fueten et al., 2008; Hauber et al., 2006) exceed the area of this embayment and appear to have subhorizontal layering that extends for many kilometers. This observation suggests an efficient transport mechanism capable of depositing large volumes evenly over large areas. By contrast, the observations here imply that these transport mechanisms were incapable of, or not available for, the even distribution of material throughout the basin.

\subsection{Post-ILD deposition and erosion}

As discussed above, the ILD deposits have been affected by erosion. At the very least, this erosion removed approximately $500 \mathrm{~m}$ of 
thickness from the southeastern edge of the central mound to create the cliff on the southeast side. Only a small debris apron surrounds the central mound and what appear to be basal layers of the deposits are visible over a wide extent of the embayment far beyond the topographic expression of the mound. In addition, a significant volume would have been removed during the faulting or slumping that created the $2 \mathrm{~km}$ to $2.5 \mathrm{~km}$ long scarps on the northwestern edge of the central mound. This observation suggests that a significant erosion event affected these layered deposits and a large volume of eroded material has been removed from the embayment. This extent of erosion is difficult to accomplish while the ancestral basin is closed and hence most likely occurred while Coprates Chasma was forming, or had already formed.

Thin mesa material covers much of the embayment, masking layered material in many locations but also showing signs of erosion. The similarity of the appearance of the thin mesa material throughout the embayment suggests that it was initially deposited as a thin, relatively uniform sheet over the entire embayment. It is unlikely that the embayment was filled with standing water after the downward movement of the linear trough of Coprates Chasma connected it to Coprates because that would also require Coprates and all connected basins to be filled to the same level. Hence, the most likely mode of forming a uniform sheet of thin mesa is by airborne ashfall. It is quite likely that the thin mesa-producing event occurred repeatedly throughout the geological history. The thin mesa material is now preserved primarily on the wall slopes and on relatively flat regions. Its absence from areas of local high elevation, such as the mounds, can be explained by more active wind erosion in those localities. Since thin mesa material covers much of the wall slopes; most of the geometry of the walls of the embayment has probably not been modified since the latest thin mesa deposition event.

\subsection{Timing of events}

The evidence suggests that ILD materials along the northern wall of Coprates Chasma were deposited in a small ancestral basin. Lower basal layers are thought to drape over an irregular underlying wall rock topography making them younger than the local wall rock of the embayment. The observations of the layered material do not lead to any direct conclusions about the mode of deposition, although the significant differences in top elevations between western and central deposits suggest that the transport mechanisms were incapable of distributing the layered material evenly throughout the embayment. The full geometry of the basin and its southern extent cannot be inferred. Lucchitta et al. (1994) and Fueten et al. (2008) argue that ILD deposition took place during early basin formation and prior to Valles Marineris formation. Fueten et al. (2008) suggest that the opening of Valles Marineris coincided with the cessation of deposition and a major erosion event. The observations presented here are compatible with the timing of that model. As has been argued above, the depositional extent of the layered deposits exceeded their present extent which indicates a significant erosion event. Since this eroded material has not been redeposited within the embayment, it must have been removed into the main part of Coprates Chasma or beyond. Hence, Coprates Chasma must have existed or was in the process of forming during the erosional event. Thin mesa material covers eroded layering and thus represents the latest event. Since this is a thin covering, the volume of deposited material following the opening of the main linear troughs of Valles Marineris is minor. This conclusion agrees with the suggestion of Fueten et al. (2008) that erosion, most likely linked to VM opening, was followed by only minor deposition.

\section{Conclusion}

Layered deposits within an embayment on the northern slope of Coprates Chasma most likely formed within a small ancestral basin.
They were emplaced upon an irregular wall rock basement and hence post-date the basement. While it is not possible to identify the mode of deposition, transport mechanisms were incapable of distributing the layered material evenly throughout the embayment. A small segment of wall rock that has been displaced downward with respect to its surroundings and covered by layered material provides the first direct visual evidence of basement collapse. Water must have been present to explain the existence of hydrated sulfates. It is impossible to identify the source of the water (precipitation versus groundwater or hydrothermal fluids). Mineralogical evidence is consistent with trends observed elsewhere with monohydrated sulfates being more common on steeper slopes. Following the deposition a significant period of erosion took place. The eroded material was removed from the embayment, most likely during or after Coprates Chasma had formed. Thin mesa most likely formed as airborne ashfall as a regionally extensive sheet and has been partially eroded since then. Since thin mesa material still covers much of the wall slope, the wall rock geometry has not been modified significantly since the last thin mesa deposition. While there are substantial differences between this study area and west Candor Chasma, the observations here are compatible with the model for ILD formation proposed by Fueten et al. (2008).

\section{Acknowledgements}

We thank the HRSC Experiment Teams at DLR Berlin and Freie Universitaet Berlin, and the Mars Express Project Teams at ESTEC and ESOC for their successful planning and acquisition of data, as well as for making the processed data available to the HRSC Team. We also want to thank the CTX, HiRISE and CRISM Teams for making their data available. This project was partially funded by an NSERC discovery grant to F. Fueten. Pangaea Scientific thanks P. Budkewitsch and Canada Centre for Remote Sensing for support of ORION under contract NRCan-01-0102. The work by P.C. McGuire has been funded by a Robert M. Walker senior research fellowship from the McDonnell Center for the Space Sciences, by a Humboldt Research Fellowship, and by support from NASA funds through the Applied Physics Laboratory, under subcontract from the Jet Propulsion Laboratory through JPL contract \#1277793. This study was also partly supported by the Helmholtz Association through the research alliance "Planetary Evolution and Life." We thank M. Lozon for preparing the illustrations. We appreciate a thorough review by Chris Okubo.

\section{References}

Catling, D.C., Wood, S.E., Leovy, C., Montgomery, D.R., Greenberg, H.M., Glein, C.R., Moore, J.M., 2006. Light-toned layered deposits in Juventae Chasma, Mars. Icarus $181,26-51$.

Chapman, M.G., 2002. Layered, massive, and thin sediments on Mars: possible Late Noachian to Late Amazonian tephra? In: Smellie, J.L., Chapman, M.G. (Eds.), Volcano-Ice Interactions on Earth and Mars: Geological Society, London, Special Publications, vol. 202, pp. 273-293.

Chapman, M.G., Tanaka, K.L., 2001. Interior trough deposits on Mars: subice volcanoes? J. Geophys. Res. 106 (E5), 10,087-10,100.

Chojnacki, M., Hynek, B.M., 2008. The geological context of water-altered minerals in Valles Marineris, Mars. J. Geophys. Res. 113, E12005. doi:10.1029/2007JE003070 Res.

Fueten, F., Stesky, R.M., MacKinnon, P., 2005. Structural attitudes of large scale layering in Valles Marineris, Mars, calculated from Mars Orbiter Laser Altimeter data and Mars Orbiter Camera imagery. Icarus 175 (1), 68-77.

Fueten, F., Stesky, R., MacKinnon, P., Hauber, E., Zegers, T., Gwinner, K., Scholten, F., Neukum, G., HRSC Co-Investigator Team, 2007. Faulting of ILD deposits on Ceti Mensa, Western Candor Chasma. Mars Lunar Planet. Sci. XXXVIII Abstract \#1388.

Fueten, F., Stesky, R., MacKinnon, P., Hauber, E., Zegers, T., Gwinner, K., Scholten, F., Neukum, G., 2008. Stratigraphy and structure of interior layered deposits in west Candor Chasma, Mars, from High Resolution Stereo Camera (HRSC) stereo imagery and derived elevations. J. Geophys. Res. 113, E10008. doi:10.1029/2007JE003053.

Gendrin, A., Mangold, N., Bibring, J.-P., Langevin, Y., Gondet, B., Poulet, F., Bonello, G., Quantin, C., Mustard, J., Arvidson, R., LeMouélic, S., 2005. Sulfates in Martian layered terrains: the OMEGA/Mars Express view. Science 307, 1587-1591. 
Hamelin, H., Racher, H., Fueten, F., Stesky, R., MacKinnon, P., Hauber, E., Gwinner, K., Scholten, F., Zegers, T., 2008. Structural analysis of an interior layered deposit in Northern Coprates Chasma, Mars. Lunar Planet. Sci. XXXIX Abstract \#1424.

Hauber, E., Gwinner, K., Gendrin, A., Fueten, F., Stesky, R., Pelkey, S., Wulf, H., Reiss, D., Zegers, T., MacKinnon, P., Michael, G., Jaumann, R., Bibring, J.-P., Neukum, G., HRSC Co-Investigator Team, 2006. An integrated study of interior layered deposits in Hebes Chasma, Valles Marineris, Mars, using MGS, MO, and MEX Data. Lunar Planet. Sci. XXXVII Abstract \#2022.

Hynek, B.M., Phillips, R.J., Arvidson, R.E., 2003. Explosive volcanism in the Tharsis region: global evidence in the Martian record. J. Geophys. Res. 108 (E9), 5111. doi:10.1029/2003JE002062.

Jaumann, R., Neukumb, G., Behnkea, T., Duxburyc, T.C., Eichentopfa, K., Flohrera, J., Gasseltb, S.V., Giesea, B., Gwinnera, K., Haubera, E., Hoffmanna, H., Hoffmeistera, A., Köhlera, U., Matza, K-D., McCordd, T.B., Mertensa, V., Obersta, J., Pischela, R., Reissa, D., Ressa, E., Roatscha, T., Saigera, P., Scholtena, F., Schwarze, G., Stephana, K. Wählischa, M., HRSC Co-Investigator Team, 2007. The high-resolution stereo camera (HRSC) experiment on Mars Express: instrument aspects and experiment conduct from interplanetary cruise through the nominal mission. Planet. Space Sci. 55, 928-952.

Komatsu, G., Geissler, P.E., Strom, R.G., Singer, R.B., 1993. Stratigraphy and erosional landforms of layered deposits in Valles Marineris, Mars. J. Geophys. Res. 98, $11,105-11,121$.

Komatsu, G., Ori, G.G., Ciarcelluti, P., Litasov, Y.D., 2004. Interior layered deposits of Valles Marineris, Mars: analogous subice volcanism related to Baikal Rifting, Southern Siberia. Planet. Space Sci. 52, 167-187.

Langevin, Y., Poulet, F., Bibring, J.-P., Gondet, B., 2005. Sulfates in the north polar region of Mars detected by OMEGA/Mars Express. Science 307 (5715), 1584-1586.

Lucchitta, B.K., 1987. Recent mafic volcanism on Mars. Science 235, 565-567.

Lucchitta, B.K., 1990. Young volcanic deposits in the Valles Marineris, Mars? Icarus 86, 476-509.

Lucchitta, B.K., Bertolini, M.L., 1990. Interior structures of Valles Marineris, Mars. 20th Lunar and Planet. Sci. Abstract \#590-591.

Lucchitta, B.K., Isbell, N.K., Howington-Kraus, A., 1994. Topography of Valles Marineris: implications for erosional and structural history. J. Geophy. Res. 99, 3783-3798.

Malin, M.C., Edgett, K.S., 2000. Sedimentary rocks of early Mars. Science 290, 927-1938.

Malin, M.C., Bell III, J.F., Cantor, B.A., Caplinger, M.A., Calvin, W.M., Clancy, R.T., Edgett, K.S., Edwards, L., Haberle, R.M., James, P.B., Lee, S.W., Ravine, M.A., Thomas, P.C., Wolff, M.J., 2007. Context camera investigation on board the Mars Reconnaissance Orbiter. J. Geophys. Res. 112, CiteID E05S04. doi:10.1029/2006JE002808.

Mangold, N., Gendrin, A., Quantin, C., Bibring, J.-P., Gondet, B., Langevin, Y., Poulet, F., Arvidson, R., Griffes, J.L., Hauber, E., Masson, P., Neukum, G., Omega Team, HRSC CoInvestigator Team, 2007a. An overview of the sulfates detected in the equatorial regions by the OMEGA/MEX spectrometer. 7th Int. Conf. Mars. Abstract \#3141.

Mangold, N., Gendrin, A., Quantin, C., Gondet, B., Bibring, J.-P., Ansan, V., Masson, P., Neukum, G., OMEGA Team, HRSC Co-Investigator Team, 2007b. Sulfate-rich deposits in West Candor Chasma. 38th Lunar and Planet. Sci. Abstract \#1643.

Mangold, N., Gendrin, A., Gondet, B., LeMouelic, A., Quantin, C., Ansan, V., Bibring, J.-P. Langevin, Y., Masson, P., Neukum, G., 2008. Spectral and geological study of the sulfate-rich region of West Candor Chasma, Mars. Icarus 194 (2), 519-543.

McEwen, A.S., Eliason, E.M., Bergstrom, J.W., Bridges, N.T., Hansen, C.J., Delamere, W.A. Grant, J.A., Gulick, V.C., Herkenhoff, K.E., Keszthelyi, L., Kirk, R.L., Mellon, M.T., Squyres, S.W., Thomas, N., Weitz, C.M., 2007. Mars reconnaissance orbiter's High Resolution Imaging Science Experiment (HiRISE). J. Geophys. Res. 112, CiteID E05S02. doi:10.1029/2005JE002605.

McGuire, P.C., Bishop, J.L., Brown, A.J., Fraeman, A.A., Marzo, G.A., Morgan, M.F., Murchie, S.L., Mustard, J.F., Parente, M., Pelkey, S.M., Roush, T.L., Seelos, F.P., Smith,
M.D., Wendt, L. and Wolff, M.J., in preparation. A new volcano-scan algorithm for atmospheric correction of CRISM and OMEGA spectral data.

Mège, D., Masson, P., 1996. Amounts of crustal stretching in Valles Marineris, Mars Planet. Space Sci. 44, 749-782.

Milliken, R.E., Swayze, G.A., Arvidson, R.E., Bishop, J.L., Clark, R.N., Ehlmann, B.L., Green, R.O., Grotzinger, J.P., Morris, R.V., Murchie, S.L., Mustard, J.F., Weitz, C., 2008. Opaline silica in young deposits on Mars. Geology 36 (11), 847-850. doi:10.1130/ G24967A.1.

Murchie, S., Arvidson, R., Bedini, P., Beisser, K., Bibring, J.-P., Bishop, J., Boldt, J., Cavender, P., Choo, T., Clancy, R.T., Darlington, E.H., Des Marais, D., Espiritu, R., Fort, D., Green, R., Guinness, E., Hayes, J., Hash, C., Heffernan, K., Hemmler, J., Heyler, G., Humm, D., Hutcheson, J., Izenberg, N., Lee, R., Lees, J., Lohr, D., Malaret, E., Martin, T. McGovern, J.A., McGuire, P., Morris, R., Mustard, J., Pelkey, S., Rhodes, E., Robinson, M., Roush, T., Schaefer, E., Seagrave, G., Seelos, F., Silverglate, P., Slavney, S., Smith, M., Shyong, W.-J., Strohbehn, K., Taylor, H., Thompson, P., Tossman, B., Wirzburger, M., Wolff, M., 2007. CRISM (Compact Reconnaissance Imaging Spectrometer for Mars) on MRO (Mars Reconnaissance Orbiter). J. Geophys. Res. 112, E05S03.

Murchie, S., Roach, L., Seelos, F., Milliken, R., Mustard, J., Arvidson, R., Wiseman, S., Lichtenberg, K., Andrews-Hanna, J., Bishop, J., Bibring, J.-P., Parente, M., Morris, R. 2009. Evidence for the origin of layered deposits in Candor Chasma, Mars, from mineral composition and hydrologic modeling. J. Geophys. Res. 114, E00D05 doi:10.1029/2009JE003343.

Nedell, S.S., Squyres, S.W., Andersen, D.W., 1987. Origin and evolution of the layered deposits in the Valles Marineris, Mars. Icarus 70, 409-441.

Okubo, C.H., McEwen, A.S., 2007. Fracture-controlled paleo-fluid flow in Candor Chasma, Mars. Science 315, 983. doi:10.1126/science.1136855.

Okubo, C.H., Schultz, R.A., Chan, M.A., Komatsu, G., High-Resolution Imaging Science Experiment (HiRISE) Team, 2009. Deformation band clusters on Mars and implications for subsurface fluid flow GSA. Bulletin 121, 474-482. doi:10.1130/B26421.1.

Pelkey, S.M., Mustard, J.F., Murchie, S., Clancy, R.T., Wolff, M., Smith, M., Milliken, R., Bibring, J.-P., Gendrin, A., Poulet, F., Langevin, Y., Gondet, B., 2007. CRISM multispectral summary products: parameterizing mineral diversity on Mars from reflectance. J. Geophys. Res. 112, E08S14.

Peterson, C., 1981. A secondary origin for the Central Plateau of Hebes Chasma. Proc 12th Lunar and Planet. Sci., Part B. Pergamon Press, New York, pp. 1459-1471.

Pondrelli, M., Pio Rossi, A., Marinangeli, L., Hauber, E., Gwinner, K., Baliva, A., Di Lorenzo, S., 2008. Evolution and depositional environments of the Eberswalde fan delta, Mars. Icarus 197, 429-451.

Quantin, C., Gendrin, A., Mangold, N., Bibring, J.-P., Hauber, E., Allemand, P., OMEGA Team, 2006. Stratigraphy and elevation of sulfate deposits in Valles Marineris. 37th Lunar and Planet. Sci. Abstract \#2046.

Rossi, A.P., Neukum, G., Pondrelli, M., van Gasselt, S., Zegers, T., Hauber, E., Chicarro, A., Foing, B., 2008. Large-scale spring deposits on Mars? J. Geophys. Res. 113, E08016. doi:10.1029/2007JE003062.

Schieber, J., 2007. Reinterpretation of the Martian Eberswalde Delta in the light of new HiRISE images. 38th Lunar and Planet. Sci. Abstract \#1982.

Schultz, R.A., 1998. Multiple-process origin of Valles Marineris basins and troughs, Mars. Planet. Space Sci. 46, 827-834.

Schultz, R.A., Lin, J., 2001. Three-dimensional normal faulting models of the Valles Marineris, Mars, and geodynamic implications. J. Geophys. Res. 106 (B8), 16,549-16,566.

Smith, M.D., Wolff, M.J., Clancy, R.T., Murchie, S.L, 2009. Compact Reconnaissance Imaging Spectrometer observations of water vapor and carbon monoxide. J Geophys. Res. 114, E00D03. doi:10.1029/2008JE003288.

Weitz, C.M., Milliken, R.E., Grant, J.A., McEwen, A.S., Williams, R.M.E., Bishop, J.L., 2008 Light toned strata and inverted channels adjacent to Juventae and Granges chasmata, Mars. Geophys. Res. Lett. 35, L19202. doi:10.1029/2008GL035317. 